\title{
Spatial and temporal variability in isotope composition of recent snow in the vicinity of Vostok station, Antarctica: implications for ice-core record interpretation
}

\author{
Alexey A. EKAYKIN, ${ }^{1,2,3}$ Vladimir Ya. LiPenKOV, ${ }^{1}$ Nargisse I. BARKOV, \\ Jean Robert PETIT, ${ }^{4}$ Valerie MASSON-DELMOTTE ${ }^{5}$ \\ ${ }^{1}$ Arctic and Antarctic Research Institute, 199397 St Petersburg, Russia \\ E-mail:ekaykin@aari.nw.ru \\ ${ }^{2}$ St Petersburg State University, 199034 St Petersburg, Russia \\ ${ }^{3}$ Université Foseph Fourier, BP 53, 38041 Grenoble Cedex 9, France \\ ${ }^{4}$ Laboratoire de Glaciologie et Géophysique de l'Environnement du CNRS, 54 rue Molière, BP 96, 38402 Saint-Martin-d'Hères Cedex, France \\ ${ }^{5}$ Laboratoire des Sciences du Climat et de l'Environnement, Orme des Merisiers, CE Saclay, 91191 Gif-sur-Yvette Cedex, France
}

\begin{abstract}
Continuous, detailed isotope $\left(\delta \mathrm{D}\right.$ and $\left.\delta^{18} \mathrm{O}\right)$ profiles were obtained from eight snow pits dug in the vicinity of Vostok station, Antarctica, during the period 19842000. In addition, snow samples taken along the $1 \mathrm{~km}$ long accumulation-stake profile were measured to determine spatial variability in isotope composition of recent snow. The stacked $\delta \mathrm{D}$ time series spanning the last 55 years shows only weak correlation with the mean annual air temperature recorded at Vostok station. Significant oscillations of both snow accumulation and snow isotope composition with the periods 2.5, 5, 20 and, possibly, $\sim 10^{2}$ years observed at single points are interpreted in terms of drift of snowaccumulation waves of various scales on the surface of the ice sheet.
\end{abstract}

\section{INTRODUGTION}

Isotope composition of precipitation $\left(\delta \mathrm{D}\right.$ or $\left.\delta^{18} \mathrm{O}\right)$ is closely related to the temperature of its formation (Dansgaard, 1964). Thus, isotope studies of ice cores may potentially provide valuable data on past climate changes (Petit and others, 1999).

It has been demonstrated (Ekaykin and others, 1998) that the drift of snow dunes is primarily responsible for temporal oscillations of accumulation rate and thus likely of isotope composition of snow at a single point (ice core). Here we attempt to interpret the short-term $\delta \mathrm{D}$ oscillations observed in the deep Vostok (Antarctica) ice core using the new data on the present-day temporal and spatial variability of snow isotope composition in the vicinity of Vostok station.

\section{METHODS AND RESULTS}

The data discussed here have been obtained from eight snow pits dug in the vicinity of Vostok station during the years 1984-2000 as depicted in Figure 1. The isotope samples were collected continuously with resolution of $2 \mathrm{~cm}$ (for pits vk14, st61, st73, vk99 and st30), $5 \mathrm{~cm}$ (vk33 and vk34) and $10 \mathrm{~cm}$ (vk31). Besides the pit studies, in January 2000 snow samples were collected near each stake of the northsouth (NS) profile of the stake network (see Fig. 1), with samples representing the upper $10 \mathrm{~cm}$ layer of snow.

The low mean annual temperature $\left(-55.4^{\circ} \mathrm{C}\right)$ and the inland location of Vostok station result in the extremely low snow-accumulation rate $\left(2.1 \mathrm{~g} \mathrm{~cm}^{-2} \mathrm{a}^{-1}\right.$; see Table 1$)$ which is responsible for the lack of seasonal variations in snow properties and frequent layer hiatus. Accordingly, all the pits were dated using the stratigraphic observations taking into account the probability of annual layer hiatus (Ekaykin and others, 1998). The initial dating was then corrected using the depths of 1955 and 1965 radioactive reference layers established for each pit, and by a comparison of snow-stratigraphy features in pits st61, st73 and st30 with accumulation measurements on the adjacent stakes located $0.1-0.3 \mathrm{~m}$ apart from the corresponding pits.

The deuterium content of the samples was measured in all eight pits, while the $\delta^{18} \mathrm{O}$ content was determined only for the samples from pits vk14, st61, st73 and vk99. The reproducibility of the measurements was estimated to be $0.6-0.8(1 \sigma)$ for $\delta \mathrm{D}$ and $0.03-0.06 \%$ for $\delta^{18} \mathrm{O}$. The $\delta \mathrm{D}$ profiles from four pits

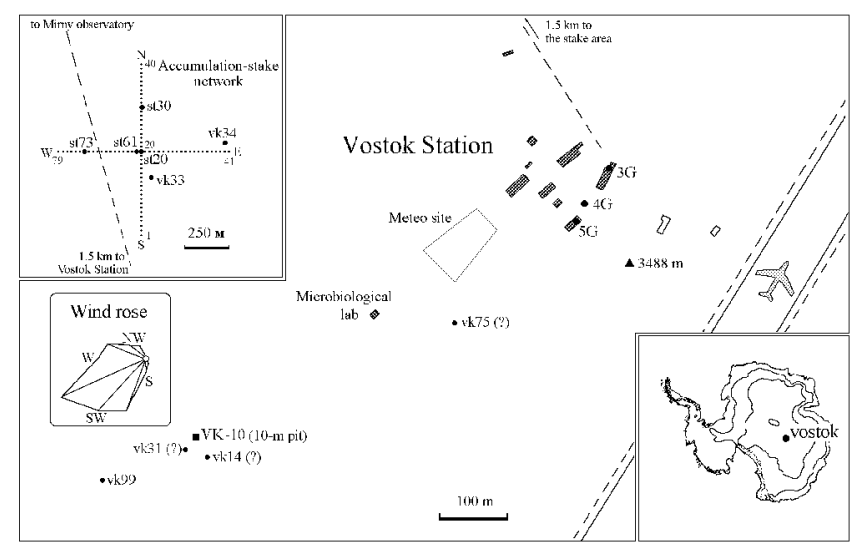

Fig. 1. A schematic map of Vostok station. The pits mentioned in this paper are shown by solid circles. Question marks refer to the pits with doubtful locations. 
Table 1. Mean values of $\delta D, \delta^{18} O$ and snow-accumulation rate for the pits studied in the vicinity of Vostok station ( see Fig. 1)

\begin{tabular}{lcccccc}
\hline Pit & Depth & \multicolumn{2}{c}{ Isotope composition } & $\begin{array}{c}\text { Period of } \\
\text { accumulation }\end{array}$ & $\begin{array}{c}\text { Accumu- } \\
\text { lation rate }\end{array}$ & Method \\
& & $\delta \mathrm{D}$ & $\delta^{18} \mathrm{O}$ & & & \\
& $\mathrm{cm}$ & $\%$ & $\%$ & & $\mathrm{~g} \mathrm{~cm}^{-2} \mathrm{a}^{-1}$ & \\
& & & & & & \\
\hline vk14 & 254 & -438.7 & -56.7 & $1942-84$ & 2.1 & strat. $+\beta$ \\
vk31 $^{*}$ & 450 & -441.0 & - & $1941-97$ & 2.3 & strat. $+\beta$ \\
vk33 $^{*}$ & 380 & -439.7 & - & $1945-97$ & 2.0 & strat. $+\beta$ \\
vk34 & 300 & -442.4 & - & $1947-97$ & 2.1 & strat. $+\beta$ \\
st61 $^{\dagger}$ & 314 & -441.4 & -56.0 & $1943-98$ & 2.0 & strat. $+\beta+$ stake \\
st73 $^{\dagger} 312$ & -436.9 & -56.5 & $1953-98$ & 2.3 & strat. $+\beta+$ stake \\
vk99 & 300 & -440.2 & -56.2 & $1949-99$ & 2.1 & strat. $+\beta$ \\
st30 $^{3} 300$ & -439.6 & - & $1944-99$ & 1.9 & strat. $+\beta+$ stake \\
& & & & & &
\end{tabular}

* The lower parts of these pits (below $362 \mathrm{~cm}$ for vk31 and below $295 \mathrm{~cm}$ for vk33) are not dated.

$\dagger \delta^{18} \mathrm{O}$ profiles are only available for the upper parts of the pits $(0-88 \mathrm{~cm}$ for st61 and $0-106 \mathrm{~cm}$ for vk99). vk99 and st 30 are $12 \mathrm{~m}$ pits, but only the first $3 \mathrm{~m}$ are studied in this paper.

are shown in Figure 2. The mean values of snow isotope composition and accumulation rate for each pit are listed in Table 1 . The average $\delta \mathrm{D}, \delta^{18} \mathrm{O}$ and $d$ values are $-440.05 \%$ o, $-56.5 \%$ and $15.1 \%$, respectively. The relationship between $\delta \mathrm{D}$ and $\delta^{18} \mathrm{O}$ (meteoric line) is given by $\delta \mathrm{D}=7.47 \delta^{18} \mathrm{O}-15.0$.
The amplitude of $d$ variations in a vertical profile is typically $5 \%$ (Fig. 2), so the accuracy of measurements required for the present study is $0.8 \%$ and $0.08 \%$ for $\delta \mathrm{D}$ and $\delta^{18} \mathrm{O}$, respectively, which provides an accuracy of $1 \%$ for the deuterium excess determination. We conclude that the accuracy of the data obtained is sufficient for the purposes of our study.

\section{DISGUSSION}

\subsection{Temporal variability of $\delta \mathrm{D}$ at Vostok station over the last 50 years}

The main feature of measured profiles (Fig. 2) is the regular oscillations of isotope composition of snow with typical wavelengths of the order of $20-30 \mathrm{~cm}$ and about $70 \mathrm{~cm}$ and with a total magnitude of about $60-80 \%$ for $\delta \mathrm{D}$, the same as the seasonal change in precipitation at Vostok (Gordienko and others, 1976). Similar oscillations have been discovered in the vicinity of Dome C, Antarctica (Petit and others, 1982), which resembles Vostok in its geographical and meteorological conditions (mean annual accumulation is $3.2 \mathrm{~g} \mathrm{~cm}^{-2}$ ).

According to pit dating, individual isotope profiles were transformed into the time series of mean-annual isotope composition of snow. The resulting time series (see Fig. 3) cover the last 40-60 years. Figure 3 shows only weak correlation between annual $\delta \mathrm{D}$ values obtained in different pits (with a

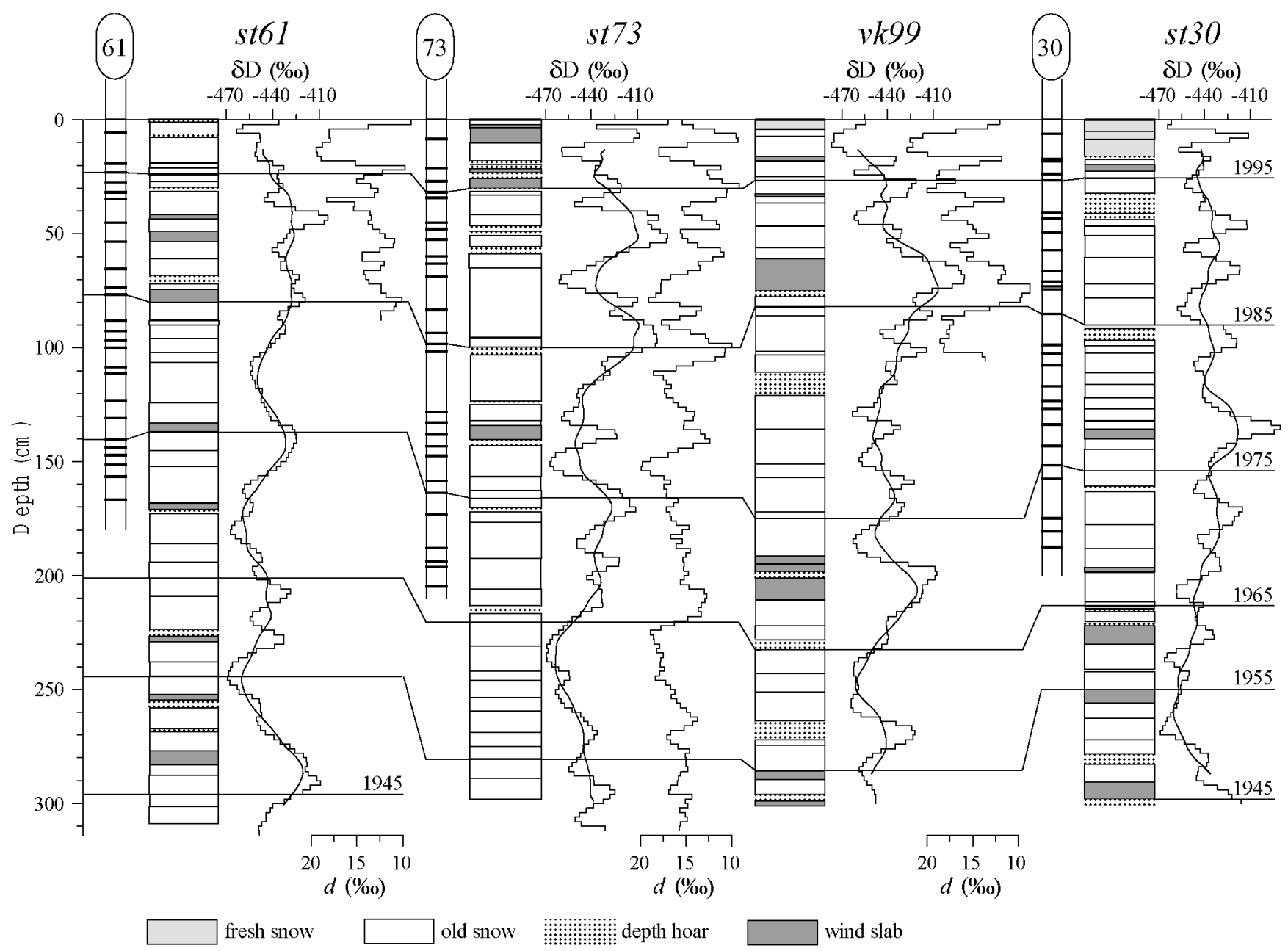

Fig. 2. The results of snow studies ( stratigraphy, $\delta D$ and d) in pits st61, st73, vk99 and st30. The annual snow build-up values measured at stakes 61, 73 and 30 were corrected for snow settling to correspond with annual layer thickness. The horizontal lines represent isochrones as indicated in the figure. Bold isochrones correspond to the reference horizons of 1955 and 1965 as determined by the total beta-activity measurements. The $\delta D$ profiles smoothed with a period of $25 \mathrm{~cm}$ are shown by thin curves. 


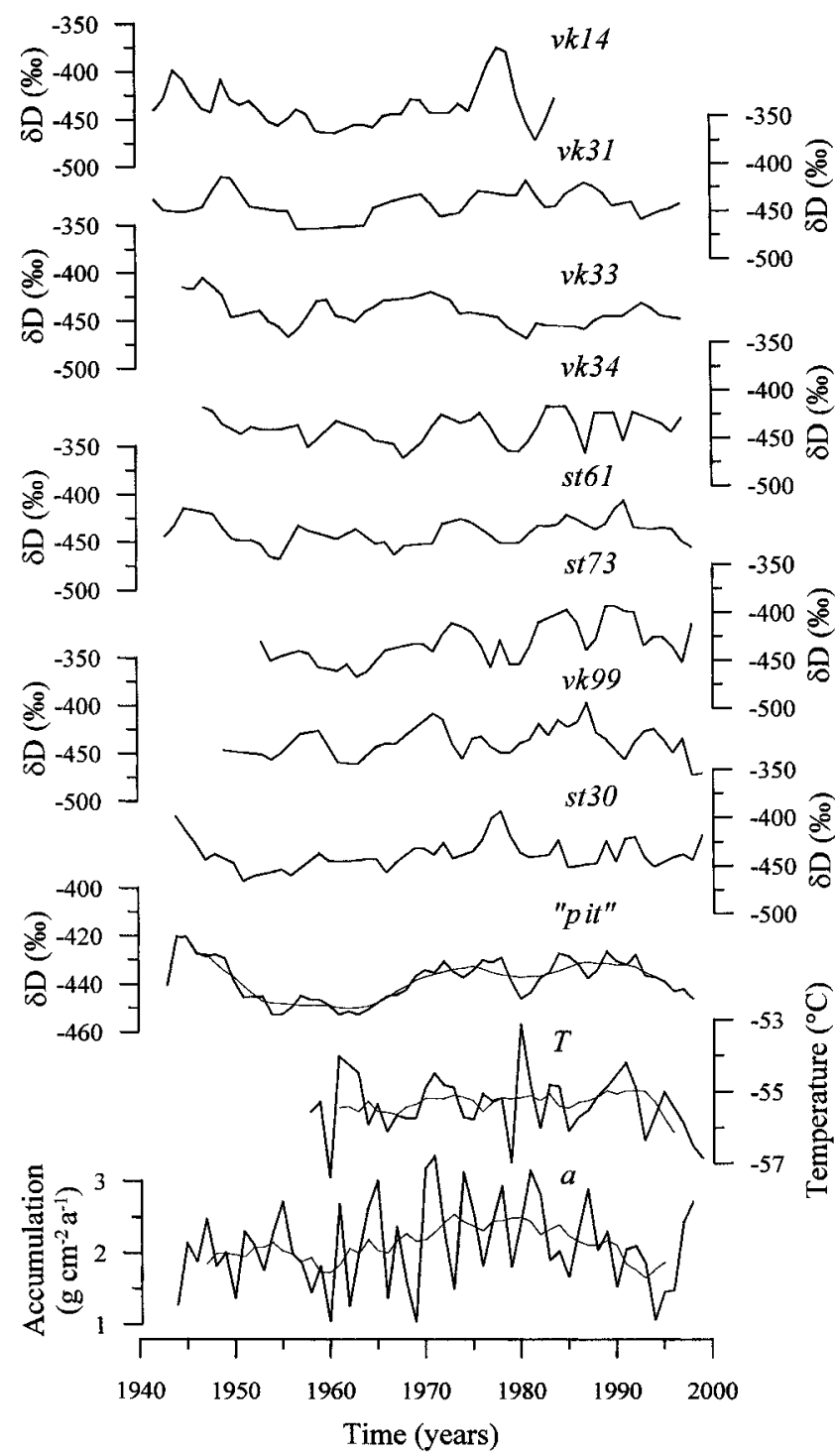

Fig. 3. The time series obtained from snow pits studied at Vostok: mean annual snow isotope composition $(\delta D)$ in the individual pits vk14-st30 and the stacked pit series; T, air temperature; $a$, snow accumulation rate. The smoothed $\mathrm{pit}, T$ and a series are shown by thin lines.

mean correlation coefficient of 0.17 ), which can be attributed to a high level of "stratigraphic noise" in the series studied (Fisher and others, 1985). This noise, linked with the extremely low accumulation rate, was previously found in snow accumulation series from the Vostok stake network (Ekaykin and others, 1998). To reduce the noise, we constructed the stacked $\delta \mathrm{D}$ time series based on the data from eight pits. The new series, hereafter referred to as pit, is also shown in Figure 3.

According to Fisher and others (1985), the signal variance in a $\delta$ series is given by $r \sigma_{\delta}^{2}$, where $\sigma_{\delta}^{2}$ is the total variance and $r$ is the correlation coefficient between two adjacent $\delta$ series. For Vostok the mean $r \sigma_{\delta}^{2}$ value equals $45 \%{ }^{2}$ (for $\delta \mathrm{D}$ ). To reduce the total variance of an individual $\delta$ series to this value, the series have to be smoothed with a period of about 20 years. This period is considered to limit the resolution of time series obtained at a single point at Vostok in terms of a possible climate signal. For the pit series the required period of smoothing is then 7 years. The smoothed pit series is shown by the thin line in Figure 3.

A comparison of both the individual and stacked $\delta \mathrm{D}$ time series with the record of mean-annual air temperature, $T$, measured at $2 \mathrm{~m}$ above the snow surface during the
Table 2. The oscillation periods observed in temporal and spatial series of snow isotope composition and accumulation rate at Vostok station. The typical wavelengths of the snow surface undulations as obtained by the snow surface levelling are also shown. See text for details

\begin{tabular}{|c|c|c|c|c|c|c|c|}
\hline \multirow{4}{*}{$\begin{array}{l}\text { Wave } \\
\text { No. }\end{array}$} & \multicolumn{3}{|c|}{ Accumulation } & \multicolumn{3}{|c|}{ Isotope composition } & \multirow{3}{*}{$\begin{array}{c}\text { Snow relief } \\
\text { Wave- } \\
\text { lengths }\end{array}$} \\
\hline & \multicolumn{2}{|c|}{$\begin{array}{l}\text { Time } \\
\text { series }\end{array}$} & $\begin{array}{l}\text { Spatial } \\
\text { profiles }\end{array}$ & $\begin{array}{l}\text { Vertical } \\
\text { profiles }\end{array}$ & $\begin{array}{l}\text { Time } \\
\text { series }\end{array}$ & $\begin{array}{l}\text { Spatial } \\
\text { profiles }\end{array}$ & \\
\hline & Stakes & Pits & Stakes & & & & \\
\hline & years & years & $\mathrm{m}$ & $\mathrm{cm} \mathrm{snow}^{* *}$ & years & $\mathrm{m}$ & $\mathrm{m}$ \\
\hline 1 & 2 & 3 & 4 & 5 & 6 & 7 & 8 \\
\hline I & 2.6 & $2-3$ & $50-60$ & $12-18$ & $2-3$ & $55-75$ & $50-60$ \\
\hline II & 5.2 & $4-5$ & $90-110$ & $20-30$ & $4-5$ & $\sim 85$ & $\sim 85$ \\
\hline III & $10-11$ & $8-11$ & - & $60-80$ & $8-14$ & - & - \\
\hline IV & ? & $\sim 20^{*}$ & $230-330$ & ? & ? & $250-330$ & $260-310$ \\
\hline V & ? & $40-50^{*}$ & - & ? & 40 & - & - \\
\hline VI & ? & $\geq 150^{*}$ & $\geq 700$ & ? & ? & $\geq 1000$ ? & $\geq 1000$ \\
\hline
\end{tabular}

\footnotetext{
* From the $10 \mathrm{~m}$ pit vk10, the data to be published elsewhere.

** The annual layer thickness in the upper $3 \mathrm{~m}$ is $5.8 \mathrm{~cm}$ on average.

Note: Column numbers are in italic. Columns $2-4$ of the table are mainly taken from Ekaykin and others (1998).
}

period 1958-98 reveals no significant correlation between the two parameters. At the same time, for smoothed stacked series (7 year running mean) the correlation becomes statistically significant $(r=0.58)$, with the $\delta \mathrm{D}-T$ slope being $17 \%{ }^{\circ} \mathrm{C}^{-1}$. Interestingly, a statistically significant slope of $20.3 \%{ }^{\circ} \mathrm{C}^{-1}$, but for non-smoothed values of the parameters, was obtained at South Pole where snow accumulation is about four times as much as that at Vostok (Jouzel and others, 1983). In both cases, the temporal slope appears to be three times greater than the spatial slope typical for this region of Antarctica (Jouzel and others, 1997), a difference which is not yet well understood.

The lowest curve in Figure 3 is the stacked series of snowaccumulation rate deduced from the stratigraphic observations in the eight pits. One can see that $\delta \mathrm{D}$ correlates more strongly with accumulation than with temperature. This could be understood if the mean annual temperature differed significantly from the mean temperature of precipitation events which were typically associated with infrequent invasions of the warm, moist air masses into the region of Vostok station.

\subsection{Spatial variability of $\delta \mathrm{D}$ of snow}

As mentioned in the Introduction, redistribution of snow by wind may produce spatial and temporal variability of snow isotope composition. Here we discuss the spatial variability of snow isotope composition at Vostok station and its possible influence on the temporal $\delta$ changes at a single point.

It has been shown (e.g. Black and Budd, 1964; Gow and Rowland, 1965; Whillans, 1975; Van der Veen and others, 1999) that the quasi-periodical spatial variability of snow accumulation with a wavelength of $2-40 \mathrm{~km}$ is caused by drifting undulations of the snow surface. Much shorter waves have been detected in the study of snow accumulation at the stake network located $1.5 \mathrm{~km}$ to the north of Vostok station (Fig. 1). Spectral analysis of the spatial series of annual snow accumulation (Ekaykin and others, 1998) revealed four types of quasi-periodical snow-accumulation waves with typical wavelengths ranging from $50-60 \mathrm{~m}$ to approximately $1 \mathrm{~km}$ (waves I, II, IV and VI; see column 4 


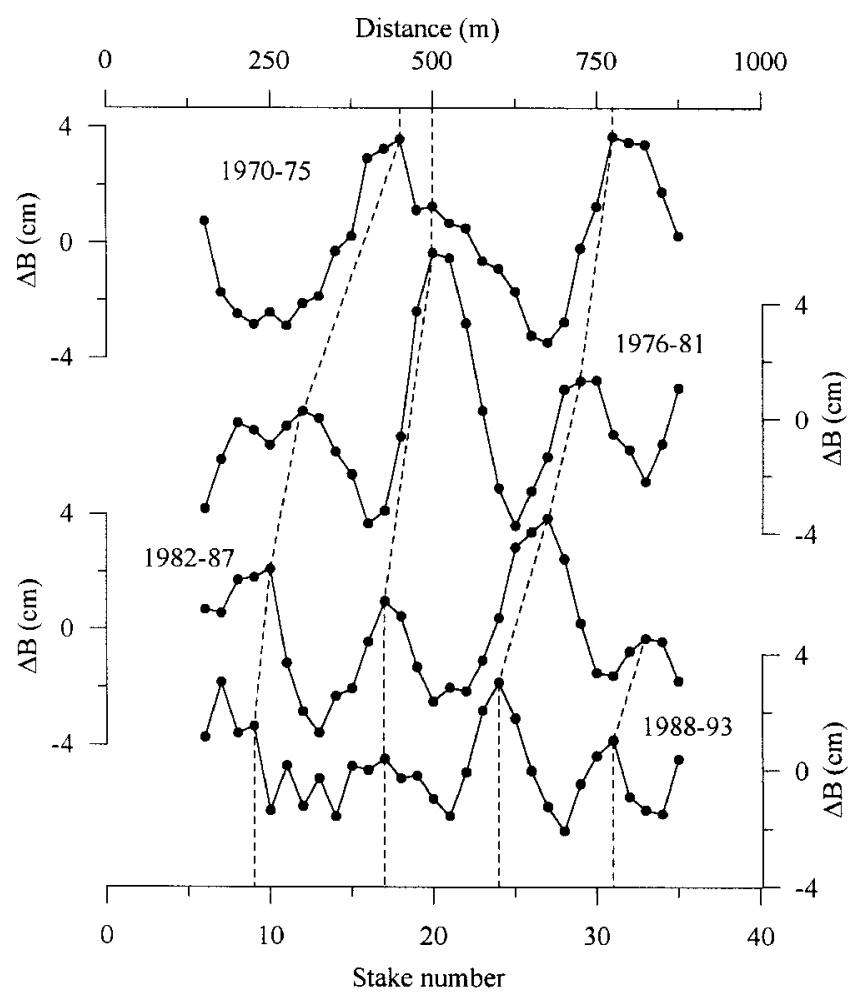

Fig. 4. Six-year snow build-up series obtained along the NS profile of the Vostok accumulation-stake network as adapted from Ekaykin and others (1998). The series were processed with a band-pass filter to extract spatial accumulation wave IV ( see Table 2). $\Delta B$ denotes deviation of snow build-up from its average over the profile.

in Table 2). The evolution with time (drift) of wave IV is shown in Figure 4, as an example. From Figure 4 it is possible to calculate the mean velocity of the wave movement (e.g. $12 \mathrm{~m} \mathrm{a}^{-1}$ for wave IV) and, thus, to estimate the typical time period of the corresponding accumulation oscillations generated at a single point ( $\sim 20$ years). Such calculations were performed for all four types of the waves observed at the stake network. The predicted periods were found to be nearly the same as the real periods established by means of spectral analysis of the accumulation time series obtained from stakes (see column 2 in Table 2) and pits (column 3). Note that the stake series are too short to allow study of spatial variations longer than waves I and II. Finally, it was concluded that periods of about 2.5, 5, 20 and of the order of $10^{2}$ years that may be found in accumulation time series obtained from a single point at Vostok station are linked with the migration of accumulation waves at the snow surface, rather than with changes in climatic conditions (Ekaykin and others, 1998).

A levelling of the snow surface performed at the stake network in December 1999 made it possible to directly compare the spatial distribution of the snow accumulation with the snow surface height. In Figure $5 a$ and b, the snow surface relief along the NS profile of the stake network is shown together with the 2 year (1998-99) snow build-up profile, both smoothed with a length scale of $125 \mathrm{~m}$. One can see a covariation between snow-relief forms and the spatial oscillations of snow accumulation. Spectral analysis of the surface profile revealed four types of surface undulations, with horizontal lengths very similar to those of the spatial accumulation waves (cf. columns 4 and 8 in Table 2). We thus conclude that comparatively short accumulation waves observed at Vostok

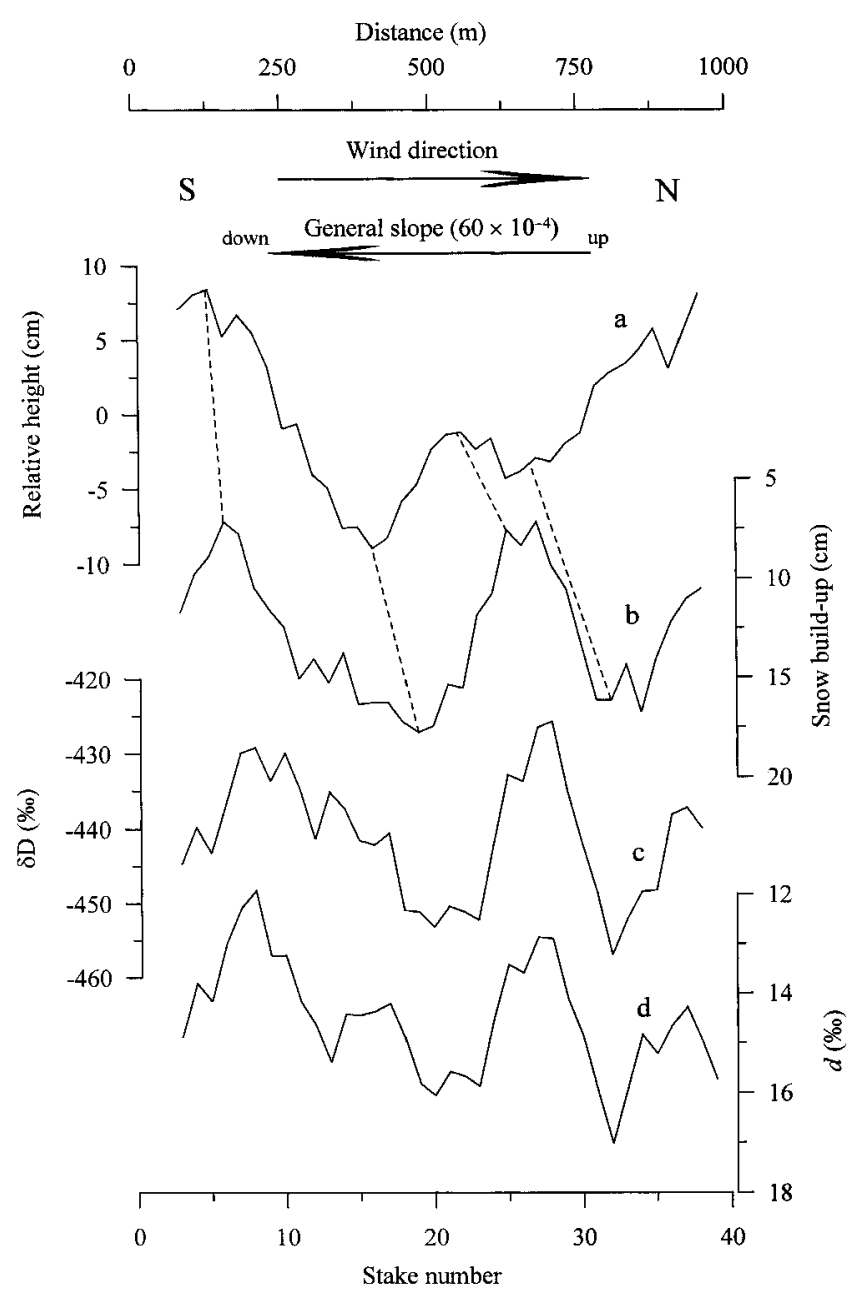

Fig. 5. The surface profile in December 1999 (a), 2 year (1998-99) snow build-up (b), $\delta D$ and d profiles ( $c$ and d, respectively) measured in $10 \mathrm{~cm}$ samples. All the profiles represent a 125 m running mean. Note that the general slope of the snow surface is subtracted from the surface profile.

are strongly linked through snow redistribution by wind with the undulations of the snow surface.

Figure $5 \mathrm{c}$ shows the profile of isotope composition of the upper $10 \mathrm{~cm}$ of snow. The negative correlation between this profile and that of accumulation (Fig. 5b) is remarkable $(r=-0.68)$. The similarity in magnitude of the spatial and seasonal $\delta \mathrm{D}$ variations suggests a spot-like spatial distribution of the winter and summer precipitation, with winter snow predominantly accumulated in the hollows of the relief, and summer snow on the bumps (see Fig. $5 \mathrm{a}$ and c). This supposition is supported by the observed strong negative correlation between the profiles of $\delta \mathrm{D}$ and $d$ (see Fig. $5 \mathrm{c}$ and $\mathrm{d}$ ) taking into account that the seasonal cycle of $d$ in central Antarctica is the inverse of that of $\delta \mathrm{D}$ (e.g. Ciais and others, 1995). Such a peculiarity in spatial distribution of seasonal snow can be explained assuming winter snow is more liable to redistribution by wind (because of smaller particles and higher wind speed during winter) than summer snow.

We can expect that, as in the case of the accumulation rate, the spatial variations of $\delta \mathrm{D}$ will also be reflected in the isotope time series. The periods of the $\delta \mathrm{D}$ oscillations revealed during the pit studies are presented in Table 2 (column 6). These periods are essentially the same as those in the accumulation time series (columns 2 and 3), which suggests that the observed oscillations have a similar origin. 


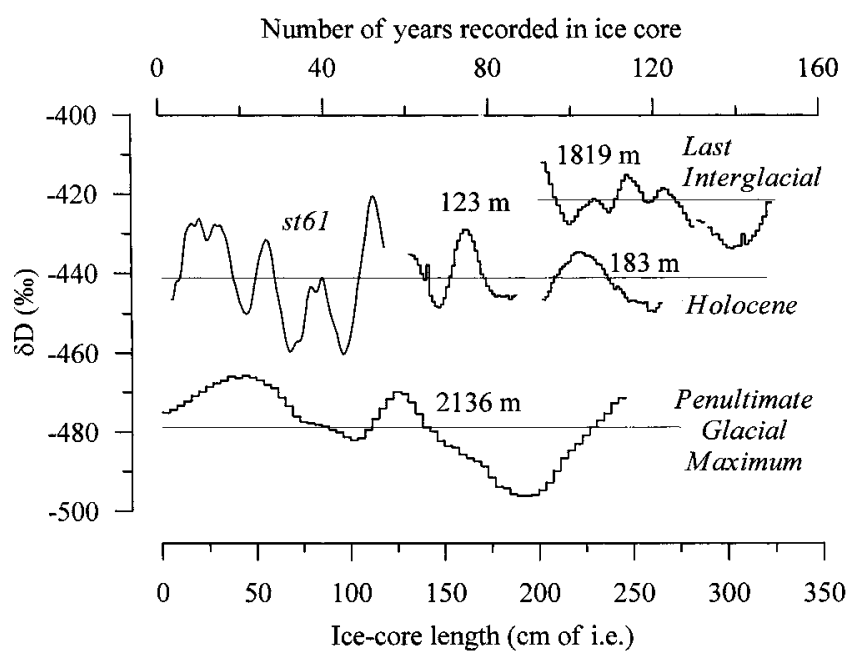

Fig. 6. Detailed isotope ( $\delta D)$ profiles measured in the Vostok ice cores from $123 \mathrm{~m}$ (the age of the ice is about $5 \mathrm{kyr}$ ), $183 \mathrm{~m}$ (8 kyr), $1819 \mathrm{~m}$ (127 kyr) and $2136 \mathrm{~m}$ (150 kyr) compared with the $\delta D$ profile from pit st 61 . The pit profile is smoothed with the period $25 \mathrm{~cm}$. All the profiles were reduced to a common time-scale (see upper axis) by correcting for annual layer thinning, density and accumulation-rate differences.

The main variations in the vertical $\delta \mathrm{D}$ profiles having a period of about $20-30 \mathrm{~cm}$ (see Fig. 2) are associated with $100 \mathrm{~m}$ long surface undulations (wave II in Table 2). To eliminate these relief-related oscillations we smooth the vertical profiles with a length scale of $25 \mathrm{~cm}$ (thin curves in Fig. 2). In the smoothed profiles, in turn, one can see relatively long oscillations with an average period of $70 \mathrm{~cm}$ which roughly corresponds to 12 years. We assume that this variation has a climatic origin. The longer oscillations cannot be seen in the individual profiles as they have comparatively small amplitudes. However, the stacked pit series (see Fig. 3) reveals $\delta \mathrm{D}$ changes with a period of $\sim 40$ years that are likely related to changes in cyclonic activity (Enomoto, 1991). The climaterelated variations with periods of about 12 and 40 years are also seen in the accumulation series (see Table 2; Fig. 3).

\subsection{Short-term $\delta \mathrm{D}$ variations in the deep Vostok core}

The results of $\delta \mathrm{D}$ measurements in the Vostok ice cores recovered from depths of 123, 183, 1819 and $2136 \mathrm{~m}$ (the ages of the ice are 5, 8, 127 and $150 \mathrm{kyr}$, respectively) are shown in Figure 6 . The profiles are reduced to a common length scale, so that an annual layer in each profile has the same thickness. The smoothed $\delta \mathrm{D}$ profile from pit st61 is shown in Figure 6 for comparison.

From Figure 6, the profiles for st61, $123 \mathrm{~m}$ and $1819 \mathrm{~m}$ have similar periods of oscillation (about 10-12 years), though the amplitude of $\delta \mathrm{D}$ variations at $1819 \mathrm{~m}$ is much weaker than in pit st61, probably due to diffusive smoothing. As for the profile from $183 \mathrm{~m}$, the wavelength ( $\geq 57 \mathrm{~cm}$ of ice, corresponding to about 25 years) is close to that of wave IV (see Table 2), though the total length of the profile leaves this result uncertain. The average period of $\delta \mathrm{D}$ variations in the core from $2136 \mathrm{~m}$ is about 44 years, which is similar to wave $\mathrm{V}$ (Table 2). Note that oscillations with periods less than 1012 years are not presented in the deep isotope profiles since they are completely erased in the process of firnification (Johnsen, 1977; Johnsen and others, 2000).

In summary, the results obtained by the study of snow accumulated at Vostok over the last 50 years provide a basis for understanding the $\delta \mathrm{D}$ variations in ice deposited in the vicinity of the station in the remote past.

\section{CONGLUSION}

Our results suggest that the $\delta \mathrm{D}$ oscillations with periods 2.5, 5 and 20 years in the vertical isotope profiles measured in the vicinity of Vostok station are mainly caused by the movement of snow-accumulation waves of various scales. Similar oscillations have been found in the snow-accumulation time series obtained at single points (Ekaykin and others, 1998).

The time period of smoothing required to sufficiently reduce the noise in a $\delta \mathrm{D}$ time series is about 20 years. We also assume a possible existence of non-climatic, reliefrelated secular $\delta \mathrm{D}$ oscillations, in which case smoothing periods much greater than 20 years may be required.

The climate-related fraction of the total variance of the isotope profiles is estimated to be about $17 \%$ and manifests itself mainly in $\delta \mathrm{D}$ oscillations with periods of 12 and 40 50 years. Moreover, the isotope composition of snow records the temperature of precipitation events, which is not representative of the mean annual air temperature.

The diffusive smoothing in the upper $3 \mathrm{~m}$ of snow at Vostok results mainly in erasure of the high-frequency variations in $\delta \mathrm{D}$ profiles. During the firnification process the $\delta \mathrm{D}$ oscillations with a period of $<20 \mathrm{~cm}$ of ice (8 years) are completely erased, which is consistent with the fact that the shortest isotope variations found in the detailed $\delta \mathrm{D}$ profiles measured in the deep Vostok ice core have periods of about 10-12 years. In general, the $\delta \mathrm{D}$ oscillations preserved in the deep core have roughly the same periods and likely the same origins as those in the near-surface snow.

\section{ACKNOWLEDGEMENTS}

We wish to thank V. N. Golubev, V. I. Nikolaev, A. N. Salamatin, S. Johnsen and J. Jouzel for valuable discussions. The manuscript was improved by comments from W. Budd and B. Smith. This work is a contribution to Project 6 of Subprogram "Study and research of the Antarctic", FTP "World Ocean" of the Russian Federation. The results presented here were obtained in the course of Russian-French collaboration on the Vostok ice core and the International Trans-Antarctic Scientific Expedition. One of the authors (A.E.) was supported by a TEMPRA grant from the French Rhône-Alpes region.

\section{REFERENGES}

Black, H. P. and W. Budd. 1964. Accumulation in the region of Wilkes, Wilkes Land, Antarctica. 7. Glaciol., 5(37), 3-15.

Ciais, P., J.W. C. White, J. Jouzel and J. R. Petit. 1995. Origin of present-day Antarctic precipitation from surface snow deuterium excess data. F. Geophys. Res., 100(D9), 18,917-18,927.

Dansgaard,W. 1964. Stable isotopes in precipitation. Tellus, 16(4), 436-468.

Ekaykin, A. A., V.Ya. Lipenkov and N. I. Barkov. 1998. Prostranstvennovremennaya struktura poly snegonakopleniya v rayone stantsii Vostok, Tsentral'naya Antarktida [The spatial and temporal structure of snow accumulation field in the vicinity of Vostok station, central Antarctica]. Vestnik St. Petersb. Un-ta, Ser. 7, 4(28), 38-50.

Enomoto, H. 1991. Fluctuations of snow accumulation in the Antarctic and sea level pressure in the Southern Hemisphere. Climatic Change, 18(1), 67-87.

Fisher, D. A., N. Reeh and H. B. Clausen. 1985. Stratigraphic noise in the time series derived from ice cores. Ann. Glaciol., 7, 76-83

Gordienko, F. G., N. I. Barkov and A. I. Orlov. 1976. Variatsii izotopnogo sostava atmosfernyh osadkov i ozernoy vody v Antarktide i Subantarktike [The variations of isotope composition of precipitation and lake 
waters in Antarctic]. Mater. Glyatsiol. Issled. 26, 150-154

Gow, A. J. and R. Rowland. 1965. On the relationship of snow accumulation to surface topography at "Byrd Station", Antarctica. f. Glaciol., 5 (42), 843-847.

Johnsen, S. J. 1977. Stable isotope homogenization of polar firn and ice. International Association of Hydrological Sciences Publication 118 (Symposium at Grenoble 1975 - Isotopes and Impurities in Snow and Ice ), 210-219.

Johnsen, S. J., H. B. Clausen, K. M. Cuffey, G. Hoffmann, J. Schwander and T. Creyts. 2000. Diffusion of stable isotopes in polar firn and ice: the isotope effect in firn diffusion. In Hondoh, T., ed. Physics of ice core records. Sapporo, Hokkaido University Press, 121-140.

Jouzel, J., L. Merlivat, J. R. Petit and C. Lorius. 1983. Climatic information over the last century deduced from a detailed isotopic record in the South Pole snow. 7. Geophys. Res., 88(C4), 2693-2703.
Jouzel, J. and 12 others. 1997. On the validity of the temperature reconstruction from water isotopes in ice cores. F. Geophys. Res., 102(C12), 26,471-26,487.

Petit, J. R., J. Jouzel, M. Pourchet and L. Merlivat. 1982. A detailed study of snow accumulation and stable isotope content in Dome C (Antarctica). 7. Geophys. Res., 87(C6), 4301-4308.

Petit, J.-R. and 18 others. 1999. Climate and atmospheric history of the past 420,000 years from the Vostok ice core, Antarctica. Nature, 399(6735), 429-436.

Van der Veen, C. J., E. Mosley-Thompson, A. Gow and B. G. Mark. 1999. Accumulation at South Pole: comparison of two 900 -year records. $\mathcal{F}$. Geophys. Res., 104(D24), 31,067-31,076.

Whillans, I. M. 1975. Effect of inversion winds on topographic detail and mass balance on inland ice sheets. F. Glaciol., 14(70), 85-90. 